\title{
Role of NO in arterial vascular function of intertidal fish (Girella laevifrons) and marine fish (Isacia conceptionis)
}

\author{
F. A. Moraga ${ }^{a *}$ and N. Urriola-Urriola ${ }^{a}$ \\ aLaboratorio de Fisiología, Hipoxia y Función Vascular, Departamento de Ciencias Biomédicas, \\ Facultad de Medicina, Universidad Católica del Norte - UCN, Larrondo 1281, Guayacán, \\ P.O. Box 117, Coquimbo, Chile \\ *e-mail: fmoraga@ucn.cl
}

Received: October 21, 2014 - Accepted: March 18, 2015 - Distributed: May 31, 2016

(With 2 figures)

\begin{abstract}
Previous studies performed in intertidal fish (Girella laevifrons), as well as marine fish (Isacia conceptionis), showed that acetylcholine $(\mathrm{ACh})$ produced contractions mediated by cyclooxygenases that were dependent on the area and potency of contraction in several arterial vessels. Given that the role of nitric oxide is poorly understood in fish, the objective of our study was to evaluate the role of nitric oxide in branchial afferent (ABA), branchial efferent (ABE), dorsal (DA) and mesenteric (MA) arterial vessels from both Girella laevifrons and Isacia conceptionis. We studied afferent and efferent branchial, dorsal and mesenteric arteries that were dissected from 6 juvenile specimens. Isometric tension studies were done using dose response curves (DRC) for Ach $\left(10^{-13}\right.$ to $\left.10^{-3} \mathrm{M}\right)$ and blockade with L-NAME $\left(10^{-5} \mathrm{M}\right)$, and DRC for sodium nitroprusside (SNP, a donor of NO). L-NAME produced an attenuation of the contractile response in the dorsal, afferent and efferent branchial arteries and a potentiation of the contraction in the MA. SNP caused $70 \%$ dilation in the mesenteric artery and $40 \%$ in the dorsal artery. Our results suggest that Ach promotes precarious dilatation in MA mediated by NO; data that is supported by the use of sodium nitroprusside. In contrast, in the vessels DA, ABA and EBA our results support that the pathway Ach-NO-relaxation is absent in both species.
\end{abstract}

Keywords: intertidal fish, marine fish, vascular reactivity, NO-pathway.

\section{Papel do NO na função vascular arterial de peixes entremarés (Girella laevifrons) e peixes marinhos (Isacia conceptionis)}

\begin{abstract}
Resumo
Estudos anteriores, realizados no peixe intertidal (Girellalaevifrons) no peixe marinho (Isacia conceptionis), mostram que a acetilcolina (Ach) provoca contrações mediadas por ciclooxigenases que eram dependentes da área e potencia da contração em vários vasos arteriais. Tendo em conta que o papel do óxido nítrico é mal compreendido em peixes, o objetivo do nosso estudo foi avaliar o papel do óxido nítrico em vasos arteriais de ambos os peixes Girella laevifrons e Isacia conceptionis. Nós estudamos os vasos aferente, branquial (ABA), eferente branquial (ABE), dorsal (DA) e mesentérica (MA), que foram dissecadas de seis espécimes juvenis. Estudos de tensão isométrica foram realizados utilizando as curvas de dose-resposta (DRC) para Ach $\left(10^{-13}\right.$ a $\left.10^{-3} \mathrm{M}\right)$ e bloqueio com L-NAME $\left(10^{-5} \mathrm{M}\right)$, e na DRC para o nitroprussiato de sódio (SNP, doador do NO). L- NAME produziu uma atenuação da resposta contrátil nas artérias dorsais, aferentes e eferentes branquial e uma potenciação da contração no MA. SNP causaram $70 \%$ da dilatação da artéria mesentérica e $40 \%$ na artéria dorsal. Nossos resultados sugerem que Ach promove dilatação precária em MA mediada por NO; dados que é suportada pela utlilização de nitroprussiato de sódio. Em contraste, nos vasos de DA, ABA e EBA nossos resultados suportam que a via de Ach-NO-relaxamento está ausente em ambas as espécies.
\end{abstract}

Palavras-chave: peixe entremarés, peixe marinho, reatividade vascular, NO-pathway.

\section{Introduction}

Physiological barriers are important determinants for the distribution limits of species and populations. However, processes associated to environmental tolerance, differential habitat use, or species distribution patterns remain poorly understood. Latitude, altitude and depth all constitute gradients that can generate physiological diversity. Indeed, intertidal rock pools are characterized by their discrete nature in time and space, as well as by 
their daily and seasonal variability in temperature, salinity and oxygen concentration during low tide (Ojeda et al., 2000). In line with this, studies carried out in our laboratory and performed using several vessels (dorsal, mesenteric, afferent and efferent branchial arteries) in G. laevifrons support the presence of two muscarinic receptors of high and low sensitivity to acetylcholine and a coupled mechanism between muscarinic receptors and vasoconstriction mediated by cyclooxygenase (Moraga and Urriola-Urriola, 2014). In contrast, Isacia conceptionis is a fish that lives in the open coast and at a depth up to $50 \mathrm{~m}$ in rocky and sandy bottom environments. The habitat of this fish species is stable suggesting that they have less stress compared with pool fish. We studied the same vessels in I. conceptionis that were studied in G. laevifrons and observed that the acetylcholine response displayed a pattern of high sensitivity only in the afferent branchial artery and low sensitivity in the dorsal, mesenteric, and efferent branchial arteries (Moraga and Urriola-Urriola, 2015). Furthermore, similar to that described for G. laevifrons, the vasoconstriction induced by Ach was abolished with indomethacine (an inhibitor of COX). Higher vasoconstriction to acetylcholine was observed in ABA and EBA in I. conceptionis in comparison with $G$. laevifrons, and a minor effect of blockade with indomethacine in the maximum response to acetylcholine was observed in ABA and DA vessels in I. conceptionis as compared to G. laevifrons. In general, the results obtained in both of these species are partially in agreement with previous studies performed in species of great phylogenetic distance (agnathes, elasmobranches, teleost), that showed that acetylcholine induced contraction (Small et al., 1990; Olson and Villa, 1991; Miller and Vanhoutte, 1992; Evans and Gunderson, 1998a). However, the Ach-mediated vasoconstriction described in our study suggests that the coupled Ach-COX contraction produced when there is a decreased availability of nitric oxide (NO) is similar to that reported in human hypertension or hypertension models in rats (Vanhoutte et al., 2005; Shi et al., 2008). In mammals, $\mathrm{NO}$ is one of the most important regulators of vascular tone and consequently of global blood pressure. In general, NO is generated by nitric oxide synthase (NOS) located in the vascular endothelium, nitrinergic nerves and macrophages in endothelium (Furchgott and Zawadzki, 1980; Griffith et al., 1984; Toda and Okamura, 2003; Donald and Broughton, 2005), and its production is coupled with stimulation by the Ach-NOS-NO-relaxation pathway. In contrast, several studies have described that this pathway is uncoupled in elasmobranches and teleost fishes (Small et al., 1990; Olson and Villa, 1991; Miller and Vanhoutte, 1992; Evans and Gunderson, 1998b). Our objective was to evaluate the role of the acetylcholine-NO pathway by blockade with L-NAME, and the dilator role of NO using sodium nitroprusside (NO donor) in the arterial vessel of dorsal, mesenteric, branchial afferent and branchial efferent arteries from the intertidal fish G. laevifrons and marine fish I. conceptionis.

\section{Material and Methods}

\subsection{Animals}

Six juvenile Girella laevifrons and six juvenile Isacia conceptionis were extracted during low tide in the Totoralillo bay $\left(30^{\circ} 17^{\prime} \mathrm{S}, 71^{\circ} 31^{\prime} \mathrm{W}\right)$ south of Coquimbo, Chile. All specimens were carried to our laboratory in the Universidad Católica del Norte and maintained for 3-5 days in filtered recirculation containers of fresh marine water at $15{ }^{\circ} \mathrm{C}$. Prior to experimentation, G. laevifrons or I. conceptionis were anaesthetized with benzocaine (1:1000) and sacrificed by decapitation. Afterward, corporal mass $(115 \pm 12$ and $140 \pm 8 \mathrm{~g})$ and longitude oral-tail $(18 \pm 0.6$ and $21 \pm 0.8 \mathrm{~cm})$ were measured for each specimen, respectively. All animal care, maintenance, procedures, and experimentation were reviewed and approved by the Faculty of Medicine Ethics Committee of the Universidad Católica del Norte.

\subsection{Bath organ physiology}

After decapitation, arterial vessels were carefully dissected from the following areas: branchial afferent (ABA), branchial efferent (ABE), dorsal (DA) and mesenteric (MA) and placed in cold $\left(4^{\circ} \mathrm{C}\right)$ physiological saline solution (PSS). Individual arterial ring segments having $2 \mathrm{~mm}$ length were mounted in a four channel small vessel wire myograph (model 510M Danish Myotech, Aarus, Denmark). The vessels were threaded onto two tungsten wires of $40 \mu \mathrm{m}$ in diameter and attached to a force transducer and a micrometer for isometric measurements. All signals were acquired by a system acquisition (Powerlab 8sp, ADInstrument, Australia) and the data collected on a personal computer for further analysis. After mounting the rings, the arterial segments were incubated in PSS at $15^{\circ} \mathrm{C}$ and gassed with air for $30 \mathrm{~min}$. Each vessel segment was stretched to its optimal diameter, i.e. the diameter at which it developed a contraction response to PSS- $\mathrm{K}^{+}$, using a diameter-tension protocol as previously described for mammalian small arteries (Stassen et al., 1997). In this way, the myograph permitted direct measurement of vessel wall tension while the internal diameter was controlled.

Following an equilibration period of at least $30 \mathrm{~min}$, doses response curves (DRC) were performed for $\mathrm{KCl}$ (5.6-125 mM) and the cholinergic agonist acetylcholine (Ach) at concentrations ranging from $10^{-13}$ to $10^{-3} \mathrm{~mol} / \mathrm{L}$. Afterward, DRC for Ach were performed in vessels pre-incubated for $30 \mathrm{~min}$ with $N^{G}$-nitro-L-arginine methyl ester (L-NAME, $10^{-5} \mathrm{M}$ ), a nitric oxide synthase inhibitor. Furthermore, DRC for sodium nitroprusside (a donor of $\mathrm{NO}$ ) were obtained at concentrations ranging from $10^{-13}$ to $10^{-3} \mathrm{~mol} / \mathrm{L}$ in arteries previously contracted with potassium chloride at $60 \mathrm{mM}$ (maximum potassium contraction). The curve is expressed as dilation of maximum contraction to potassium and represents maximum dilation (Dmax). Between experiments, the arterial preparations were allowed to recover for at least 30-60 min to return to resting basal tension.

The PSS contained (in $\mathrm{g} / \mathrm{L}$ ): $\mathrm{NaCl} 7.37, \mathrm{KCl} 0.31$, $\mathrm{KH}_{2} \mathrm{PO}_{4} 0.46, \mathrm{Na}_{2} \mathrm{HPO}_{4} 2.02, \mathrm{MgSO}_{4} 0.14, \mathrm{CaCl}_{2} 0.1$, glucose 0.9 with $\mathrm{pH}$ adjusted to 7.8 (Olson and Villa. 
1991). For the PSS- $\mathrm{K}^{+}$solution $(125 \mathrm{mM} \mathrm{KCl}), \mathrm{NaCl}$ was replaced by an equimolar amount of $\mathrm{KCl}$. All chemicals were reagent grade and purchased from Sigma Chemical (St Louis, MO, USA). The following drugs used in the study: acetylcholine (Ach), $N^{G}$-nitro-L-arginine methyl ester (L-NAME), and sodium nitroprusside (SNP) were purchased from Sigma Chemical (St Louis, MO, USA).

\subsection{Data analysis and statistics}

DRC were analyzed in terms of maximal response (Rmax), sensitivity $\left(\mathrm{EC}_{50}\right.$ or $\left.\mathrm{pEC}_{50}\right)$ and maximum dilation (Dmax) to different contractile agents by fitting the individual data with a nonlinear sigmoid regression curve (Prism 4.0, Graphpad, San Diego, CA, USA). Rmax was expressed as $(\mathrm{N} / \mathrm{m})$ and Dmax was expressed as $\left(\% \mathrm{~K}^{+} \max \right)$. Sensitivity was expressed as $\mathrm{EC}_{50}$ (the concentration of agonist at which $50 \%$ of Rmax was obtained) or as $\mathrm{pEC}_{50}\left(-\operatorname{logEC} \mathrm{C}_{50}\right)$.

In order to evaluate the role of the Ach-NOS-NO-relaxation pathway, data were expressed as ratio response (RR) of Rmax Ach plus LNAME divided by Rmax of Ach, the evaluation of the ratio response (RR) should give values of $R R>1$ if there is an increase in wall tension due to decreased production of $\mathrm{NO}$ mediated by Ach, and values of $\mathrm{RR}=1$ Ach-NOS-NO-relaxation is uncoupled and $\mathrm{RR}<1$, Ach promote dilation don't mediated by NO.

All results were expressed as mean \pm SEM. A two way ANOVA for repeated measurements was used for statistical analysis of physiological variables. Differences were considered significant when $p<0.05$ (Primer of Biostatistical v 3.0, Mc Graw Hill).

\section{Results}

The calculated internal diameter for all arteries is given in Table 1. The data show that not differences were observed in the optimal diameter determined for each of the arterial segments from the different territories studied in both species.

\subsection{Response to potassium chloride $(\mathrm{KCl})$}

Table 2 provides a summary for Rmax parameters obtained from analysis of the arterial response curves in both species. These data reveal that Rmax was significantly greater in the $\mathrm{ABA}$ and $\mathrm{ABE}$ in I. conceptions as compared to $G$. laevifrons. No differences were observed between DA and MA in both species. In addition, no differences were observed in the $\mathrm{EC}_{50}$ in any of the arteries evaluated in both species.

\subsection{Response blockade with L-NAME to acetylcholine}

In Figure 1 we can observe an increase in the contractile response to Ach, only in MA in comparison with DA, ABA and EBA. On the other hand, in DA was observed such as maintenance. However, a dilation response was observed in
ABA and EBA to Ach. On other hand, significant differences were observed between species in ABA, EBA and MA, but not in DA. Table 2 summarizes the Rmax values obtained from analysis of the arterial curves. No differences were observed in the $\mathrm{pEC}_{50}$ in any of the arteries evaluated.

\subsection{Response to sodium nitroprusside (a NO donor)}

In order to evaluate the role of $\mathrm{NO}$, arteries were pre-contracted by Ach, and DRC for SNP $\left(10^{-13}-10^{-10} \mathrm{M}\right)$ were evaluated. Figure 2 reveals that the mesenteric artery exhibited dilation close to $70 \%$, whereas the dorsal artery only had dilation close to $40 \%$. No effect in dilation was found in ABA and ABE in the presence of SNP. Table 2 summarizes the $\mathrm{pEC}_{50}$ and $\mathrm{Rmax}$ values obtained from analysis of the arterial curves. No differences were observed in the $\mathrm{pEC}_{50}$ in any of the arteries evaluated.

\section{Discussion}

Our study compared vascular function of two fish with completely different habitats: G. laevifrons that lives and develops in an environment with extreme variation (intertide), and $I$. conceptionis that lives in an environment with little variation (open coast). Previously, we demonstrated that both species possess a vasoconstrictor mechanism mediated by acetylcholine supporting the presence of two muscarinic receptors: one having high sensitivity and a second one of lower sensitivity coupled to different mechanisms of activation (Moraga and Urriola-Urriola, 2014, 2015).

\subsection{Role of L-NAME in the Ach-mediated contraction}

Our results show that all vessels studied (ABA, EBA, MA and DA) exhibited a similar pattern of vasoconstriction mediated by Ach as previously described by Moraga and Urriola-Urriola $(2014,2015)$, in the same species. In addition,

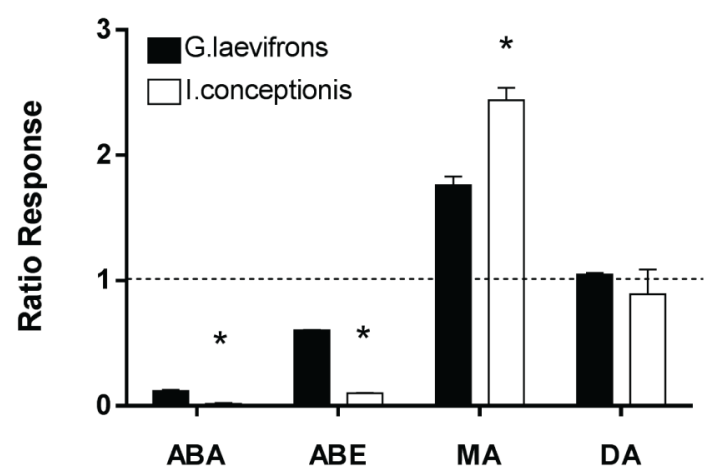

Figure 1. Ratio response in G.laevifrons (black) and I.conceptionis (open) from afferent branchial artery (ABA); efferent branchial artery (EBA); mesenteric artery (MA) and dorsal artery (DA). Each symbol represents the mean \pm s.e.m. ${ }^{*} \mathrm{p}<0.05$ G.laevifrons vs I. conceptionis.

Table 1. Optimal diameter $(\mu \mathrm{m})$ in arterial vessel of marine fish.

\begin{tabular}{ccccc}
\hline & ABA & EBA & MA & DA \\
\hline G. laevifrons (6) & $475 \pm 103$ & $413 \pm 54$ & $366 \pm 58$ & $488 \pm 108$ \\
I. conceptionis (6) & $425 \pm 83$ & $430 \pm 44$ & $408 \pm 98$ & $406 \pm 88$ \\
\hline
\end{tabular}

Mean \pm s.e.m. and number (n). 
Table 2. Dose response curves to acetylcholine and L-NAME in several vascular vessels.

\begin{tabular}{|c|c|c|c|c|c|}
\hline & & $\mathbf{A B A}$ & EBA & MA & DA \\
\hline \multicolumn{6}{|l|}{ CCR-K } \\
\hline G. laevifrons. & $\begin{array}{c}\mathrm{EC}_{50}(\mathrm{mM}) \\
\operatorname{Rmax}(\mathrm{N} / \mathrm{m})\end{array}$ & $\begin{array}{r}21.5 \pm 8.5 \\
2.4 \pm 0.4\end{array}$ & $\begin{array}{r}25.3 \pm 5.7 \\
1.8 \pm 0.4\end{array}$ & $\begin{array}{r}27.3 \pm 5.3 \\
1.5 \pm 0.3\end{array}$ & $\begin{array}{r}22.3 \pm 5.3 \\
2.2 \pm 0.2\end{array}$ \\
\hline I. conceptionis & $\begin{array}{c}\mathrm{EC}_{50}(\mathrm{mM}) \\
\operatorname{Rmax}(\mathrm{N} / \mathrm{m})\end{array}$ & $\begin{array}{c}15,8 \pm 3.6 \\
7.2 \pm 0.6 * ף\end{array}$ & $\begin{array}{c}16.7 \pm 3.2 * \\
3.1 \pm 0.9 *\end{array}$ & $\begin{array}{c}19.0 \pm 3.2 * \\
1.3 \pm 0.2\end{array}$ & $\begin{array}{r}17.7 \pm 2.7 \\
2.7 \pm 0.4\end{array}$ \\
\hline \multicolumn{6}{|l|}{ CCR-Ach } \\
\hline G. laevifrons. & $\operatorname{Rmax}(\mathrm{N} / \mathrm{m})$ & $0.84 \pm 0.02$ & $0.68 \pm 0.06$ & $1.47 \pm 0.09^{\dagger}$ & $3.87 \pm 0.16^{\ddagger}$ \\
\hline I. conceptionis & $\operatorname{Rmax}(\mathrm{N} / \mathrm{m})$ & $5.98 \pm 0.38 * \approx$ & $3.93 \pm 0.21 *$ & $1.46 \pm 0.02^{\dagger}$ & $3.93 \pm 0.2$ \\
\hline \multicolumn{6}{|l|}{ CCR- L-NAME } \\
\hline G. laevifrons. & $\operatorname{Rmax}(\mathrm{N} / \mathrm{m})$ & $0.21 \pm 0.03$ & $0.41 \pm 0.03$ & $2.59 \pm 0.17^{\dagger}$ & $4.06 \pm 0.22$ \\
\hline I. conceptionis & $\operatorname{Rmax}(\mathrm{N} / \mathrm{m})$ & $0.16 \pm 0.05$ & $0.40 \pm 0.04$ & $3.56 \pm 0.5^{*}$ & $3.50 \pm 0.8^{\S}$ \\
\hline \multicolumn{6}{|l|}{ CCR-SNP } \\
\hline \multirow[t]{2}{*}{ G. laevifrons. } & $\mathrm{pEC}_{50}(\mathrm{mM})$ & $9.34 \pm 1.20^{\dagger \dagger}$ & $10.26 \pm 1.91^{\dagger \dagger}$ & $7.20 \pm 0.39$ & $7.30 \pm 0.35$ \\
\hline & $\operatorname{Dmax}\left(\% \mathrm{~K}^{+} \max \right)$ & $2.0 \pm 0.88$ & $1.0 \pm 0.89$ & $70.0 \pm 5.4^{\dagger}$ & $40.0 \pm 2.90 \S$ \\
\hline \multirow[t]{2}{*}{ I. conceptionis } & $\mathrm{pEC}_{50}(\mathrm{mM})$ & $8.94 \pm 1.20^{\dagger \dagger}$ & $9.86 \pm 1.00^{\dagger \dagger}$ & $6.58 \pm 0.59$ & $7.31 \pm 0.83$ \\
\hline & $\operatorname{Dmax}\left(\% \mathrm{~K}^{+} \max \right)$ & $12.0 \pm 4.8^{*}$ & $25.0 \pm 4.1 *$ & $61.0 \pm 0.7^{\dagger}$ & $42.3 \pm 3.0 \S$ \\
\hline
\end{tabular}

Mean \pm s.e.m. * G. laevifrons vs I. conceptionis. $\uparrow$ ABA vs DA, EBA and MA. $\dagger$ MA vs DA, ABA and EBA. $\ddagger$ DA vs ABA, EBA and MA. $\S$ DA vs ABA and EBA. †† EBA vs DA, ABA and $\mathrm{MA}(\mathrm{P}<0.05)$.
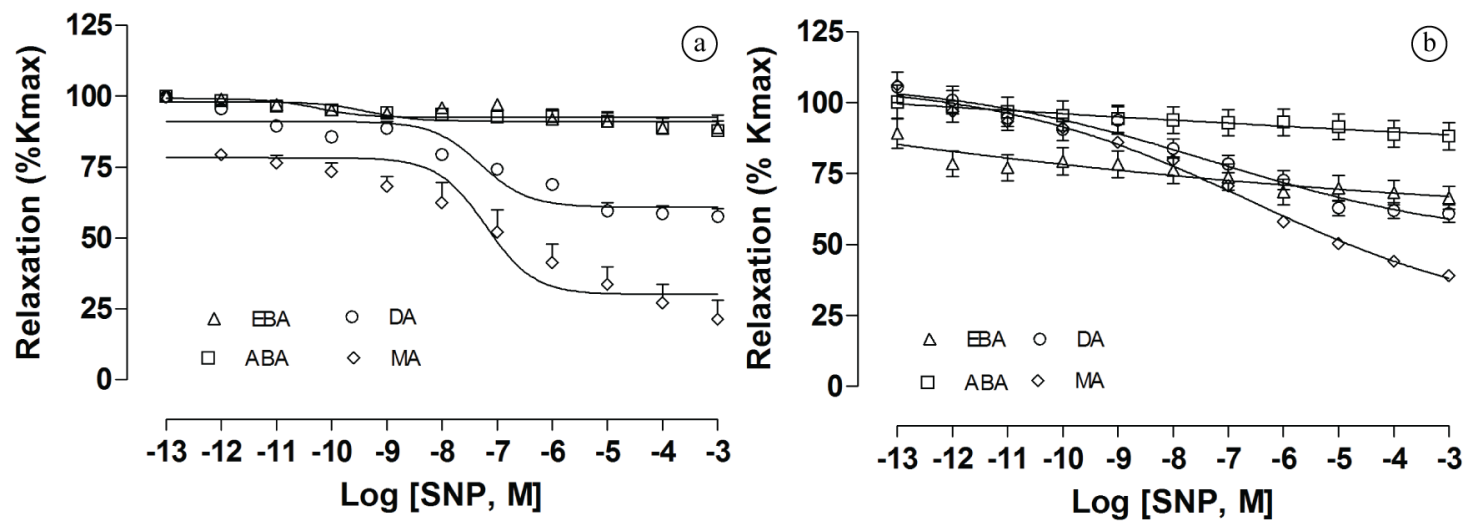

Figure 2. Sodium nitroprusside concentration-response curves in: (a) G.laevifrons (black) and (b) I.conceptionis (open) of isolated rings of arteries from afferent branchial artery (ABA, squares); efferent branchial artery (EBA, triangles); mesenteric artery (MA, rhombus) and dorsal artery (DA, circles) each symbol represents the mean \pm s.e.m.

the same authors describe that this vasoconstriction was abolished by the use of atropine $\left(10^{-5} \mathrm{M}\right)$. This evidence has been corroborated by other studies in trout, shark and eel (Nilsson and Grove, 1974; Pellegrino et al., 2003; Pellegrino et al., 2002; Small et al., 1990), supporting the presence of muscarinic receptors in fish vasculature.

In mammalian vascular endothelium, several extracellular signals can stimulate NOS, increasing the production of NO, including Ach, shear stress, etc. (Furchgott and Zawadzki, 1980). The nitric oxide produced by endothelium rapidly diffuses into the smooth muscle cell where it activates a soluble guanylyl cyclase (sGC), which generates cyclic guanosine monophosphate (cGMP) that mediates vasodilation (Mondaca et al., 1991). A traditional approach to evaluate coupled Ach-dilation is by the use of blocking agents that inhibit NOS, decreasing NO production, such as L-NAME or others (Buxton et al., 1993). The expected effect of blocking NO production would be an increase in the basal tension, or an increase in the Ach-mediated tension. Therefore, evaluation of the ratio response (RR) should give values of $R R>1$ if there is an increase in wall tension due to decreased production of NO mediated by Ach, and values of $R R=1$ or $R R<1$ if Ach-NOS-NO-relaxation is uncoupled. Indeed, studies show that there is an absence of muscarinic receptors coupled to the NOS-NO dilation pathway in fish (Donald and Broughton, 2005). In contrast, our results revealed a different effect when blocking with L-NAME in the arterial vessel. For example, in $\mathrm{ABA}$ and $\mathrm{ABE}$ there was a reduction in the Ach-mediated vasoconstriction suggesting 
activation of other mediators that promote vasodilation, such as prostacyclin, $\mathrm{H}_{2} \mathrm{~S}$ or CO (Olson and Villa, 1991; Miller and Vanhoutte, 1986; Evans and Gunderson, 1998b; Feng et al., 2007; Dombkowski et al., 2008; Jennings and Donald., 2010). On the other hand, DA did not modify arterial tension in the presence or absence of L-NAME, supporting the lack of Ach-NOS-NO-relaxation coupling. In MA, we described an increase in Ach-mediated vasoconstriction indicating the presence of a coupled Ach-NOS-NO dilation. This evidence suggests that there is Ach-NOS-NO-relaxation coupling in MA in both species, such as that shown in Danio rerio in the same vascular area (Fritsche et al., 2000; Holmberg et al., 2006).

\subsection{Role of SNP in vascular dilation}

In order to corroborate the role of $\mathrm{NO}$, we studied the effect of SNP, a NO donor, in all the vessels. We found that $\mathrm{ABA}$ and $\mathrm{ABE}$ in $G$. laevifrons were insensitive to stimulation with SNP, and a poor response in the same vessel was observed in I. conceptionis. The lack or poor response to SNP in these areas suggests a different mechanism of activation for vessel dilation, independent of NO. This lack of dilation in the fish vessels studied was also described in the isolated ventral aorta of O. mykiss (Miller and Vanhoutte, 1992). In addition, an eel contraction response in the presence of SNP was described by Pellegrino et al. (2002) suggesting that NO could be mediated via reaction with superoxide ions to produce the very reactive peroxynitrite that promotes vasoconstriction (Beckman and Koppenol, 1996) by a reduction in the bioavailability of $\mathrm{NO}$ and a stimulation of COX that promotes the production of vasoconstrictors. In contrast, our results show dilatators response of $70 \%$ in Girella laevifrons and $60 \%$ were observed in Isacia conceptionis, in MA, and dilation close to $40 \%$ in DA in both species. This evidence supports a coupled mechanism of dilation in these vessels mediated by the NO-GMPc-relaxation pathway. Furthermore, our results are in agreement with the presence of SNP-mediated dilation described in arteries of the trout $(O$. mykiss $)$ : coronary, celiacomesenteric and efferent branchial (Olson and Villa, 1991; Small et al. 1990; Olson et al., 1991, Olson et al., 1997).

In conclusion, our results suggest differences in the vascular function between I. conceptions and. G. laevifrons, could be explained by ontogenic, habitat and/or phylogenetic components Furthermore, our results suggest that the MA expresses a vascular response when the Ach-NOS-NO relaxation pathway is coupled, whereas the results in DA, ABA and EBA suggest the presence of another mechanism. Future studies are needed to further evaluate the vascular response in these species.

\section{Acknowledgements}

We are grateful for the technical assistance of Mr. Hervis Galleguillos and Medical Students Carolina Norero, Daniela Gonzalez, Natalia Soto and Marietta Nuñez who collaborated in the experiments. This research was partially supported by project DGIP 10301272, Universidad Católica del Norte.

\section{References}

BECKMAN, J.S. and KOPPENOL, W.H., 1996. Nitric oxide, superoxide, and peroxynitrite: the good, the bad, and ugly. The American Journal of Physiology, vol. 271, no. 5 Pt 1, pp. C1424-C1437. PMid:8944624.

BUXTON, I.L., CHEEK, D.J., ECKMAN, D., WESTFALL, D.P., SANDERS, K.M. and KEEF, K.D., 1993. NG-nitro L-arginine methyl ester and other alkyl esters of arginine are muscarinic receptor antagonists. Circulation Research, vol. 72, no. 2, pp. 387395. http://dx.doi.org/10.1161/01.RES.72.2.387. PMid:7678206.

DOMBKOWSKI, R.A., WHITFIELD, N.L., MOTTERLINI, R., GAO, Y. and OLSON, K.R., 2008. Effects of carbon monoxide on trout and lamprey vessels. American Journal of Physiology: Regulatory, Integrative and Comparative Physiology, vol. 296, no. 1, pp. R141-R149. http://dx.doi.org/10.1152/ajpregu.90507.2008. PMid:19005018.

DONALD, J.A. and BROUGHTON, B.R., 2005. Nitric oxide control of lower vertebrate blood vessels by vasomotor nerves. Comparative Biochemistry and Physiology. Part A, Molecular \& Integrative Physiology, vol. 142, no. 2, pp. 188-197. http://dx.doi. org/10.1016/j.cbpa.2005.07.015. PMid:16139537.

EVANS, D.H. and GUNDERSON, M.P., 1998a. A prostaglandin, not NO, mediates endothelium-dependent dilation in ventral aorta of shark (Squalus acanthias). The American Journal of Physiology, vol. 274, no. 4 Pt 2, pp. R1050-R1057. PMid:9575968.

EVANS, D.H. and GUNDERSON, M.P., 1998b. Functional characterization of a muscarinic receptor in the smooth muscle of the shark (Squalus acanthias). Experimental Biology Online, vol. 3, no. 3, pp. 3. http://dx.doi.org/10.1007/s00898-998-0003-5.

FENG, J., YANO, K., MONAHAN-EARLEY, R., MORGAN, E.S., DVORAK, A.M., SELLKE, F.W. and AIRD, W.C., 2007. Vascular bed-specific endothelium-dependent vasomomotor relaxation in the hagfish, Myxine glutinosa. American Journal of Physiology: Regulatory, Integrative and Comparative Physiology, vol. 293, no. 2, pp. R894-R900. http://dx.doi.org/10.1152/ajpregu.00080.2007. PMid:17537844.

FRITSCHE, R., SCHWERTE, R. and PELSTER, B., 2000. Nitric oxide and vascular reactivity in developing zebrafish, Danio rerio. American Journal of Physiology. Regulatory, Integrative and Comparative Physiology, vol. 279, no. 6, pp. R2200-R2207. PMid:11080086.

FURCHGOTT, R.F. and ZAWADZKI, J.V., 1980. The obligatory role of endothelial cells in the relaxation of arterial smooth muscle by acetylcholine. Nature, vol. 288, no. 5789, pp. 373-376. http:// dx.doi.org/10.1038/288373a0. PMid:6253831.

GRIFFITH, T.M., HENDERSON, A.H., EDWARDS, D.H. and LEWIS, M.J., 1984. Isolated perfused rabbit coronary artery and aortic strip preparations: the role of endothelium-derived relaxant factor. The Journal of Physiology, vol. 351, no. 1, pp. 13-24. http://dx.doi.org/10.1113/jphysiol.1984.sp015228. PMid:6611406.

HOLMBERG, A., OLSSON, C. and HOLMGREN, S., 2006. The effects of endogenous and nitric oxide on gut motility in zebrafish Danio rerio embryos and larvae. The Journal of Experimental Biology, vol. 209, no. Pt 13, pp. 2472-2479. http:// dx.doi.org/10.1242/jeb.02272. PMid:16788030.

JENNINGS, B.L. and DONALD, J.A., 2010. Mechanisms of nitric oxide-mediated, neurogenic vasodilation in mesenteric resistance arteries of toad Bufo marinus. American Journal of Physiology: Regulatory, Integrative and Comparative Physiology, vol. 298, no. 
3, pp. R767-R775. http://dx.doi.org/10.1152/ajpregu.00148.2009. PMid:20071617.

MILLER, V.M. and VANHOUTTE, P.M., 1986. Endotheliumdependent responses in isolated blood vessels of lower vertebrates. Blood Vessels, vol. 23, no. 4-5, pp. 225-235. PMid:3490888.

MILLER, V.M. and VANHOUTTE, P.M., 1992. Endotheliumdependent vascular responsiveness: evolutionary aspects. In: U.S. RYAN and G.M. RUVANYI. Endothelial regulation of vascular tone. New York: Marcel Dekker, pp. 3-20.

MONDACA, S., PALMER, R.M.J. and HIGGS, E.A., 1991. Nitric oxide physiology, pathophysiology and pharmacology. Pharmacological Reviews, vol. 120, pp. 227-237.

MORAGA, F.A. and URRIOLA-URRIOLA, N., 2014. Vascular function in arteries of intertidal fish Girella laevifrons (Kyphosidae). Brazilian Journal of Biology = Revista Brasileira de Biologia, vol. 74, no. 3, pp. 739-743. http://dx.doi.org/10.1590/bjb.2014.0099. PMid:25296227.

MORAGA, F.A. and URRIOLA-URRIOLA, N., 2015. Acetylcholine produces contraction mediated by cyclooxigenase pathway in arterial vessels in the marine fish (Isacia conceptionis). Brazilian Journal of Biology $=$ Revista Brasileira de Biologia, vol. 75, no. 2, pp. 362-367. http://dx.doi.org/10.1590/1519-6984.13413. PMid:26132019.

NILSSON, S. and GROVE, D.J., 1974. Adrenergic and cholinergic innervation of the spleen of the cod: Gadus morhua. European Journal of Pharmacology, vol. 28, no. 1, pp. 135-143. http:// dx.doi.org/10.1016/0014-2999(74)90124-1. PMid:4430318.

OJEDA, F.P., LABRA, F. and MUÑOZ, A., 2000. Patrones biogeográficos de los peces litorales de Chile. Revista Chilena de Historia Natural, vol. 73, no. 4, pp. 625-641.

OLSON, K.R. and VILLA, J., 1991. Evidence against nonprostanoid endothelium-derived relaxing factor(s) in trout vessels. The American Journal of Physiology, vol. 260, no. 5 Pt 2, pp. R925-R933. PMid:2035704.

OLSON, K.R., CONKLIN, D.J., FARRELL, A.P., KEEN, J.E., TAKEI, Y., WEAVER, L. Jr., SMITH, M.P. and ZHANG, Y., 1997. Effects of natriuretic peptides and nitroprusside on venous function in trout. The American Journal of Physiology, vol. 273, no. 2 Pt 2, pp. R527-R539. PMid:9277535.
OLSON, K.R., DUFF, D.W., FARRELL, A.P., KEEN, J., KELLOGG, M.D., KULLMAN, D. and VILLA, J., 1991. Cardiovascular effects of endothelin in trout. The American Journal of Physiology, vol. 260, no. 4 Pt 2, pp. H1214-H1223. PMid:1826412.

PELLEGRINO, D., ACIERNO, R. and TOTA, B., 2003. Control of cardiovascular function in the icefish Chionodraco hamatus: involvement of serotonin and nitric oxide. Comparative Biochemistry and Physiology. Part A, Molecular \& Integrative Physiology, vol. 134, no. 2, pp. 471-480. http://dx.doi.org/10.1016/S10956433(02)00324-0. PMid:12547277.

PELLEGRINO, D., SPROVIERI, E., MAZZA, R., RANDALL, D.J. and TOTA, B., 2002. Nitric oxide-cGMP-mediated vasoconstriction and effects of acetylcholine in the branchial circulation of the eel. Comparative Biochemistry and Physiology. Part A, Molecular \& Integrative Physiology, vol. 132, no. 2, pp. 447-457. http:// dx.doi.org/10.1016/S1095-6433(02)00082-X. PMid:12020661.

SHI, Y., MAN, R.Y. and VANHOUTTE, P.M., 2008. Two isoforms of cyclooxygenase contribute to augmented endotheliumdependent contractions in femoral arteries of 1-year-old rats. Acta Pharmacologica Sinica, vol. 29, no. 2, pp. 185-192. http:// dx.doi.org/10.1111/j.1745-7254.2008.00749.x. PMid:18215347.

SMALL, S.A., MACDONALD, C. and FARRELL, A.P., 1990. Vascular reactivity of the coronary artery in rainbow trout (Oncorhynchus mykiss). The American Journal of Physiology, vol. 258, no. 6 Pt 2, pp. R1402-R1410. PMid:2360689.

STASSEN, F.R., RAAT, N.J., BROUWERS-CEILER, D.L., FAZZI, G.E., SMITS, J.F. and MEY, J.G., 1997. Angiotensin II induces media hypertrophy and hyperreactivity in mesenteric but not epigastric small arteries of the rat. Journal of Vascular Research, vol. 34, no. 4, pp. 289-297. http://dx.doi.org/10.1159/000159236. PMid:9256089.

TODA, N. and OKAMURA, T., 2003. The pharmacology of nitric oxide in the peripheral nervous system of blood vessels. Pharmacological Reviews, vol. 55, no. 2, pp. 271-324. http:// dx.doi.org/10.1124/pr.55.2.3. PMid:12773630.

VANHOUTTE, P.M., FELETOU, M. and TADDEI, S., 2005. Endothelium-dependent contractions in hypertension. British Journal of Pharmacology, vol. 144, no. 4, pp. 449-458. http:// dx.doi.org/10.1038/sj.bjp.0706042. PMid:15655530. 